\title{
Thinking and Seeing with Women in Revelation, by Lynn Huber
}

The Library of New Testament Studies | London: T. \& T. Clark, 20I3 | 224 pages | ISBN: 978-0-567662-6I-3 (softcover) $£$ I 8.99

In this book, Lynn Huber highlights two key conceptual frameworks which can aid us in understanding the book of Revelation and its reception: metaphor

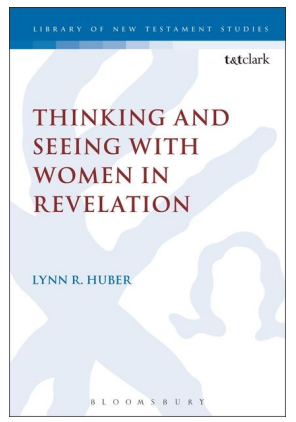
and vision. These facets of the text, Huber persuasively argues, are central to the imaginative pull of Revelation. They are at the heart of John's appeal to ancient readers and subsequent visionary authors and artists.

In the Introduction, Huber demonstrates that Revelation's climactic vision of the marriage of the Lamb and Bride is prefigured even in the text's opening word: apokalypsis, or unveiling. She demonstrates that John's depiction of female characters such as "bride" and "whore" carried deep resonances 
within contemporary culture. The text's blending of metaphorical concepts attached to these characters is thus key to its critique of Roman cultural and political mores. Revelation's rhetoric, Huber argues, creates a symbolic world in which the audience can participate, and which in turn shapes how they see the world.

These insights are fleshed out in the book's first two chapters. In the first, Huber underscores the importance of "seeing with" John as a hermeneutical key to Revelation. Huber draws attention to the visual nature of John's rhetoric, aligning John's repeated commands to "look!" with the ancient technique of ekphrasis - prompting the reader to envision a scenario in order to accept the narrator's evaluation. The otherworldly nature of the text's visions prompts its author to draw upon metaphor and simile as vehicles for conveying his experiences. This, for Huber, allows us to draw upon modern conceptual metaphor theories to explore how the author constructs the women in his text. Huber's second chapter is thus dedicated to setting Revelation's metaphorical imagery in context. She notes that John's metaphors draw upon concepts which resonated both within contemporary Roman culture and the author's Jewish scriptural heritage. In particular, John regularly uses the metaphors of "woman" and "city" in the construction of his text, presenting the whore of Babylon and New Jerusalem as images of communal identity.

Chapter three offers a reading of Rev I7-22, paying close attention to the depiction of Revelation's key women, Babylon and Jerusalem. Huber offers a detailed and sensitive mapping of the metaphorical concepts and domains which John blends to create these women/cities. She reads Revelation's use of the "prostitute" metaphor alongside contemporary Roman attitudes to honour and sexuality. She also makes instructive use of contemporary depictions of powerful prostitutes such as Messalina in Juvenal's sixth satire. Her analysis of Revelation's depiction of New Jerusalem offers a similarly rigorous exploration of associations with the concepts of "bride" and "wedding" in John's cultural and political context. One facet of the Revelation's metaphorical equation of women and cities is especially brought to the foreground in $\mathrm{Hu}-$ ber's analysis: the notion of the woman/city as a "container." She highlights how both women are construed as containers for communities: one afflicted by vice (Babylon), and one faithful (New Jerusalem). Revelation exploits this mapping of women as cities and, therefore, containers, in a number of ways. It can be used to convey the sense of security of a protected community, or it can be used to construct a woman/city as a prison. 
The final two chapters of the book draw upon these central metaphors at the heart of Revelation's rhetorical construction of Babylon and New Jerusalem. By paying attention to how the text was received and interpreted by two medieval visionaries and two modern visionary women, Huber demonstrates how Revelation's metaphors survive and evolve in the imaginations of later readers. Chapter 4 shows how Hildegard of Bingen and Hadewijch of Brabant use Revelation's metaphors to explore the text's meaning in new cultural contexts. Huber first demonstrates how Hildegard of Bingen uses Revelation's "woman" metaphor to depict God's faithful community. Huber explores how Hildegard develops John's imagery by emphasising the domain's associations with procreation and motherhood. In her analysis of Hadewijch's visions, Huber shows how the visionary redirects the communal emphasis in Revelation's metaphors and instead uses them to explore the experience of the individual contemplative soul. In this way, Huber demonstrates that Hildegard and Hadewijch did not just restate John's visions. Instead, they draw upon Revelation's imagery to explore new meanings inherent in the text's metaphorical mappings. They depict the "woman" as community and mother; as individual and bride.

This exploration of the development of Revelation's metaphorical mappings of "woman" and "city" culminates in Huber's exploration of the art of two twentieth-century readers: Sister Gertrude Morgan and Myrtice West. Huber contextualises Morgan's and West's careers against the backdrop of modern American evangelicalism, before recounting how Morgan draws upon Revelation in her art. Huber's analysis is rich in detail, and she pays close attention to Morgan's self-portraits. Huber shows how Morgan presents herself as the source domain for Revelation's bridal imagery. This in turn, is used by Morgan to think through the theological ramifications of a personal relationship with Jesus and God and its effects upon a wider believing community. The concept of marriage stands alongside the New Jerusalem as key subjects in Morgan's art, and Huber shows how Morgan's illustrations New Jerusalem Court, Gloryland St., and The New Jerusalem situated Revelation's vision of the New Jerusalem in the present. Huber explores how Morgan, through her visions and illustrations, finds herself represented by the women in Revelation. West uses Revelation's metaphors to explore her own identity and the text's meaning in her own context. In doing so she resists John's prohibition against altering the text (Rev 22:18-19).

Huber finds a similar affirmation of an artist's right to appropriate Revelation's metaphors in Myrtice West's paintings. Huber analyses three of 
West's paintings in the Revelation Series and shows how West further blurs the domains of "city" and "woman" in her depiction of Babylon. West depicts her own murdered daughter as Christ's "bride" and thus places special emphasis on Revelation's "wedding" metaphor as the focus of the text's promises. Morgan's and West's adaptations of Revelation's metaphors, for Huber, have a dual purpose: they provide tools to explore their own experiences, and they provide opportunities to shape their own audience's understanding of the text's promises.

In the book's epilogue, Huber reflects on how Hildegard, Hadewijch, Morgan, and West create new associations between Revelation's metaphors. Huber concludes that these women were able to counter John's own attempts to render the women in his text passive. They used the text's own metaphors and images to assert their own voices against contemporary patriarchal norms.

Huber's book navigates several complex areas of scholarship in a lucid and engaging manner. The book is a gold mine both for readers interested in the first-century context of the book of Revelation, and those interested in its interpretation in different cultural contexts. Huber draws on a breadth of material to contextualise the metaphors at the heart of Revelation's portrayal of women. She also offers a wealth of detail as she charts the reception of these metaphors in the visions of later writers.

While reading the book, I found Huber's use of conceptual metaphor theory helpful. The index of "Conceptual Metaphors and Blends" at the end of the book is a particularly helpful aid for the reader. I particularly enjoyed the way she used the method to pare down Revelation's dense imagery to its constituent metaphorical mappings. This is a useful tool for the study of the text's reception history. It shows how metaphors such as "woman" and "city" work upon the imaginations of interpreters at a distance of one millennium or two millennia from the original source text. Hildegard, Hadewijch, Morgan, and West can thus speak the same language as the visionary author that inspires them, and can thus challenge his metaphorical mappings using his own terms. Huber's detailed exposition of these later visionaries' works, however, underscores the force of the women's own rhetoric in their own times. She highlights how their appropriations of John's visions force his metaphors to yield new meanings and connotations.

Huber's book leaves open further avenues for exploration. By her own admission, there was insufficient space to discuss the construction of the woman of Rev I2. This character has inspired many later visionaries. She has also 
been used by female interpreters, artists and prophets to explore their identity. Characters such as Jezebel also play an important role in Revelation's construction and subjugation of women. Yet this is not brought up by way of criticism of Huber's project. Rather, it underscores that there is much mileage to be had in the thought-provoking analysis Huber offers. Her book unveils how John sees the women in his narrative. It also shows how Revelation's women engender new metaphorical mappings when seen afresh in new contexts. This book is thus a helpful and instructive contribution to the debate surrounding how the reception of texts can contribute to the task of interpretation.

Jonathan Downing Trinity College 